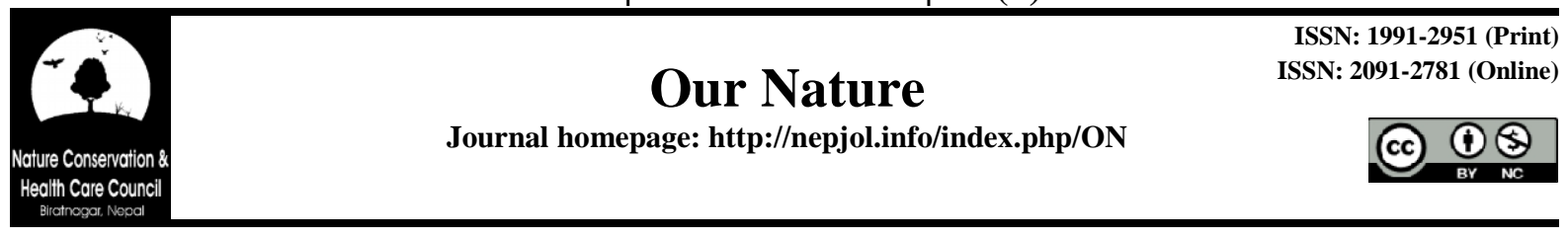

\title{
Species diversity of macrophytes in Jagadishpur Reservoir, Kapilvastu District, Nepal
}

\author{
R.K. Chaudhary and A. Devkota* \\ Central Department of Botany, Tribhuvan University, Kirtipur, Kathmandu, Nepal \\ ${ }^{*}$ E-mail: devkotaa@gmail.com
}

\begin{abstract}
The present research was conducted for quantitative study and diversity analyses of aquatic macrophytes dwelling littoral zone of Jagadishpur reservoir, Kapilvastu district in three seasons, as winter (December), summer (April), and rainy (August). Altogether 58 species of macrophytes were recorded in study site, of which highest number of species (54) was occupied by angiosperms followed by three species of pteridophytes and one species of alga. These macrophytes varied in different morphological groups, viz., emergent, submerged, and rooted-floating leaf type. Maximum number of species were represented by emergents (39) followed by rooted-floating leaf type (12) and submerged (7) macrophytes. There was distinct seasonal variation in the distribution of macrophytes: based on importance value index, Nelumbo nucifera (IVI $=22.87$ ), Scripus sp. $(\mathrm{IVI}=28.01)$, Ipomoea carnea $(\mathrm{IVI}=24.67)$ and Typha angustifolia $(\mathrm{IVI}=$ 29.01) were dominant in the winter; Nelumbo nucifera (IVI = 20.05), Cynodon dactylon $(\mathrm{IVI}=20.07)$ and Ipomoea carnea $(\mathrm{IVI}=21.17)$ were dominant in the summer and Nelumbo nucifera $(\mathrm{IVI}=23.8$ ) and Scripus sp. (IVI =25.56) were dominant in the rainy season. The highest species diversity (H') of macrophytes was observed during summer (3.451), followed by rainy season (3.135) and winter (3.008). The luxuriant growth of aquatic macrophytes evidenced the highly productive nature of the lake, while the dominance of emergents among the growth forms indicates the encroachment of littoral vegetation, indicating a successional trend toward marsh meadow.
\end{abstract}

Key words: Diversity index, emergents, growth forms, importance value index

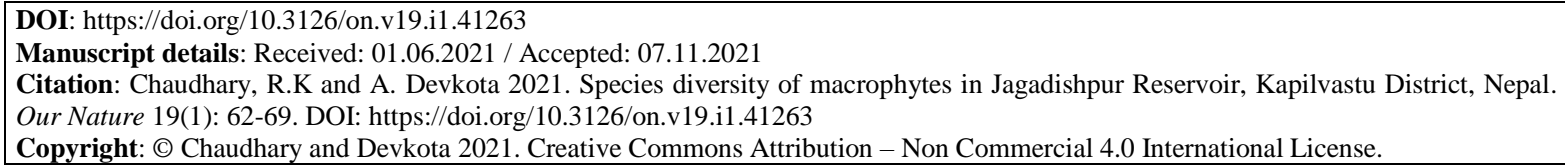

\section{Introduction}

Biodiversity is one of the most important characteristics of the aquatic ecosystem for maintaining its stability and resilience (Singh and Sharma, 2014). Aquatic macrophytes are macroscopic forms of aquatic vegetation, including macro algae, mosses, ferns and angiosperms found in aquatic habitat. They are considered as an important component of the aquatic ecosystem not only as the habitat and food source for aquatic life, but also act as an efficient accumulator of heavy metals (Chung and Jeng, 1974; Scheffer, 1989; Acharya, 1997) and as an important participant in the natural processes of self-purification of water (Dembitsky et al., 1992). Macrophytes have evolved from many diverse groups and often demonstrate extreme plasticity in structure and morphology in relation to changing environmental condition (Wetzel, 1983). In different growth forms a macrophytes represent the most important biotic element of the littoral zone in a lake ecosystem (Piecznyska, 1990). Number of species and importance values (numbers, biomass, productivity and so on)) of individuals, determine the species diversity of a 
community (Odum, 1996). Importance value index (IVI), a quantitative parameter is useful as it provides an overall picture of the density, frequency and cover of a species in relation to community (Curtis and McIntosh, 1951).

Most of the lakes on the plains of the Terai are oxbow systems (Sharma, 1973) and possess a luxuriant growth of aquatic vegetation (BPP, 1995; Bhandari, 1998). Some of lakes are already on the verge of disappearance whereas others are highly vulnerable to degradation due to physiographic features as well as anthropogenic activities (BPP, 1995; Bhandari, 1998).

Nepal's wetlands are facing degradation mainly due to drainage, land reclamation, pollution and over-exploitation of wetland species. Also the accumulation of nitrogen, phosphorous and pesticides from agricultural runoff leads to severe degradation of wetlands, especially the lakes (Niraula, 2012).

The quantitative seasonal analysis of the macrophytic composition of the littoral zone of the low land lake may provide baseline information for formulating conservation and management strategies. A considerable contribution on the aquatic macrophytes of Nepal has been made by several researchers (Sah, 1997; Bhandari, 1998; Burlakoti and Karmacharya, 2004; Kunwar and Devkota, 2012; Bhusal and Devkota, 2020). Although, some scattered reports are available on the lowland lakes of Nepal. The quantitative analyses on the macrophytes of the Jagadishpur reservoir has not been carried out yet. As the quantity and diversity of macrophytes are the important parameters for assessing the health of the ecosystem. Hence, the present study aimed to assess the richness and composition of macrophytes of the lake in terms of seasonal variation. This study is expected to be helpful in designing a plan for the sustainable management of the lake.

\section{Materials and methods}

\section{Study area}

Jagadishpur Reservoir $\left(27^{\circ} 37 . \mathrm{N}\right.$ and $83^{\circ} 06^{\prime} \mathrm{E}$, alt. $197 \mathrm{~m}$ asl) lies in Kapilvastu Municipality - 9, Kapilvastu District, Province no. 5, Lumbini zone, Central Nepal; about $10 \mathrm{~km}$ north from Taulihawa districts headquarter of Kapilvastu (Fig. 1). The Reservoir was impounded in 1972 by diverting the Banganga River for irrigation purpose. Currently, it is a largest reservoir in the country constructed for irrigation with a total area of 225 ha and water surface area of 157 ha (Baral and Inskipp, 2005). The reservoir is the main source of water for irrigation of at least 406 ha land in the Kapilvastu district. The water level in the reservoir fluctuates from a maximum of 5$7 \mathrm{~m}$ to a minimum of 2-3 m (Dhonju, 2010). This site is considered as paradise for birds. It provides shelter to at least 18 species of mammals, 8 species of reptiles, 42 species of indigenous and migratory birds and 25 species of fishes (Baral and Inskipp, 2005). Similarly, several plant species occur in the reservoir and the adjoining areas. The area is famous for its biodiversity. Southwest part has been used for recreation (boating) purpose. Based on the above criteria the Jagadishpur reservoir has been designated as Ramsar site in 2003. The area is characterized by the tropical monsoon climate with hot and rainy summer and cool and dry winter (Dhonju, 2010).

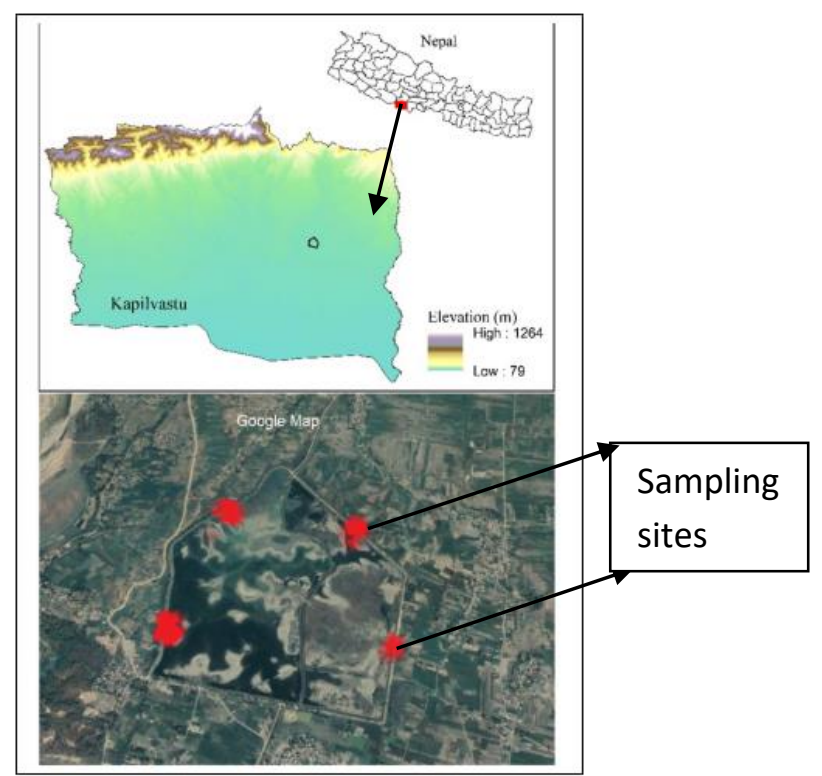

Figure 1. Location map of Jagadishpur reservoir locating sampling sites. 


\section{Chaudhary and Devkota / Our Nature | December 2021 | 19(1): 62-69}

\section{Macrophyte sampling}

Quantitative parameters of Jagadishpur reservoir were studied in the littoral zone of four different sites (Fig. 1) during three seasons, winter (December), summer (April), and rainy (August). These four sites were selected for macrophytes sampling as representative of the entire lake system. To analyze the macrophytes community, we applied a random sampling method along several transects, with the help of $1 \mathrm{~m} \times 1 \mathrm{~m}$. light wooden quadrat. The quadrat size was determined by species area curve method as mentioned in Zobel et al. (1987). Ten quadrats on each transect of four sides were taken. Altogether 120 quadrats were studied in three different seasons.

Importance Value Index (IVI) was calculated by adding the relative values of density, frequency and cover (by visual estimation) following Zobel et al. (1987). Diversity index $\left(H^{\prime}\right)$ was calculated following the Shannon and Weiner formula: $\mathrm{H}^{\prime}=-\Sigma \mathrm{pi}^{*} \log$ pi; where, $\mathrm{pi}=$ the proportion of importance value of the $i^{\text {th }}$ species, $\mathrm{pi}=\mathrm{ni} / \mathrm{N}$, ni is the importance value of $\mathrm{i}^{\text {th }}$ species and $\mathrm{N}$ is the importance value of all the species (Zobel et al. 1987). The plant species were identified with the help of standard literature (Khan and Halim, 1987; Gurung, 1991; Cook, 1996; Press et al., 2000).

Macrophytes in the present study were categorized into three main growth forms following Shrestha (1998). Rooted plants with main photosynthetic parts projecting above the water surface were classified as emergents, rooted plants with leaves floating on the water surface were classified as rooted floating species, and macrophytes rooted or floating plants completely or; largely submerged were classified as submerged macrophytes.

\section{Results and discussion}

\section{Quantitative analysis}

Altogether 58 species of macrophytes were recorded in study site, which belongs to 29 families and 50 genera of which seven were submerged, 12 were rooted-floating and 39 were emergent species by growth form (Figs. 2 and 3). Out of them, highest number of species (54) was occupied by angiosperms followed by three species of pteridophytes and one species of alga (Table 1). The highest number of emergent over the rooted floating and the submerged species was substantiated by the findings of Shrestha
(1998), Burlakoti and Karmacharya (2004), and Sharma and Singh (2017). The highest number of angiospermic species by taxonomic groups may be attributed to influence of tropical climate. Unsuitable environment in wetland may limit terrestrial pteridophyte species. Only one species of macroscpoic alga, i.e., Chara aspera was reported from the reservoir.

\section{Importance Value Index (IVI)}

The dominance of species by growth forms on the basis of IVI value is presented in table 1 . The number of aquatic macrophyte species was higher during the rainy season (57) and winter (54) and lower during the summer (46) (Table 1). The relatively higher number of species indicated shallow depth area with fine sediment, advancing eutrophic condition (Nichols, 1992). Emergents macrophytes were the most dominant form throughout the year. This can be attributed to the emergents' high tolerance for fluctuation of water level (Valk and Davis, 1976). Annual average of IVI values of emergent were found to be dominant (185.17) followed by the rooted floating (64.44) and submerged (49.45) macrophytes. Seasonally, emergents' IVI was highest in the summer, followed by winter and rainy.

Among emergents, Scripus sp. was the most dominant in the winter (IVI: 28.01) and the rainy season (IVI: 25.56), and Ipomoea carnea (IVI: 20.98), Cynodon dactylon (IVI:15.82) and Typha angustifolia (IVI: 10.77) were dominant during all seasons (Table 1). Out of these $C$. dactylon showed better growth during winter and summer seasons. This might be due to lowered water level and mostly dry water land. Similar result was observed by Dinerstein (1974) who observed that emergent species like $C$. dactylon was dominantly found in open, dry and highly disturbed areas. After emergents, the next highest IVI values were those of Rooted floating species, viz., Nelumbo nucifera (IVI: 22.24), Nymphaea nouchali (IVI: 6.91), Hygroryza aristata (IVI: 6.81) in all seasons, and submerged species as Hydrilla verticillata (IVI: 13.55) and Potamogeton crispus (IVI: 5.77) in all seasons. The dense growth of free-floating and rooted floating-leaved species prevented colonization of submerged species in the summer and the winter season (Kaul et al., 1978).

The vigorous year-round growth of $H$. verticillata, indicates its ability to adapt in 
diverse conditions. Similar findings regarding $H$. verticillata were reported by Acharya (1997) and Shrestha (2000). Shinghal and Singh (1978) also reported this species in a lake area characterized by high silt load and cultural eutrophication. The silt load and the eutrophication in the Jagadishpur reservoir were found to be due to the transportation of silt, organic matter and litter from the catchment area at the time of flooding.

Table 1. Seasonal variation of IVI values of macrophytes by growth form.

\begin{tabular}{|c|c|c|c|c|c|}
\hline \multirow{3}{*}{ Growth form } & \multirow{3}{*}{ Group } & \multicolumn{3}{|c|}{ Importance Value Index } & \multirow{3}{*}{ Average } \\
\hline & & & & & \\
\hline & & Winter & Summer & Rainy & \\
\hline \multicolumn{6}{|l|}{ Submerged } \\
\hline Chara aspera Willdenow & $\mathrm{Al}$ & 10.56 & - & 11.27 & 10.91 \\
\hline Hydrilla verticillata (L. f.) Royle & Am & 17.15 & 8.56 & 14.96 & 13.55 \\
\hline Ottelia alismoides (L.) Pers. & Am & 1.59 & 3.95 & - & 2.77 \\
\hline Potamogeton crispus L. & Am & 5.8 & 4.08 & 6.43 & 5.77 \\
\hline Potamogeton nodosus Poir. & Am & 4.8 & 3.62 & 4.27 & 4.89 \\
\hline Potamogeton octandrus Poir. & Am & 5.53 & 6.03 & 7.33 & 6.29 \\
\hline Potamogeton pectinatus L. & Am & 5.72 & 6.66 & 6.44 & 6.27 \\
\hline Total & & 51.15 & 32.9 & 50.7 & 49.45 \\
\hline \multicolumn{6}{|l|}{ Rooted floating } \\
\hline Aponogeton natans (L.) Engl. \& K. Krause & $\mathrm{Am}$ & 1.14 & 2.90 & 1.12 & 1.72 \\
\hline Azolla imbricata Roxb. ex Griff.) Nakai & $\mathrm{P}$ & 2.79 & 6.16 & 6.35 & 5.1 \\
\hline Eichhornia crassipes (Mart.) Solms & $\mathrm{Am}$ & 1.78 & 3.73 & 5.4 & 1.83 \\
\hline Hygroryza aristata (Retz.) Nees ex Wight \& Arn. & Am & 5.47 & 8.11 & 6.85 & 6.81 \\
\hline Ipomoea aquatica Forssk. & Ad & 2.33 & 5.90 & 1.56 & 3.26 \\
\hline Marsilea minuta $\mathrm{L}$. & $\mathrm{P}$ & - & 6.63 & 4.46 & 5.54 \\
\hline Nelumbo nucifera Gaertn. & Ad & 22.87 & 20.05 & 23.80 & 22.24 \\
\hline Nymphaea nouchali Burm. f. & Ad & 6.48 & 6.09 & 8.17 & 6.91 \\
\hline Nymphoides hydrophylum (Lour.) Kuntze & Ad & 5.25 & - & 2.83 & 4.04 \\
\hline Nymphoides indica (L.) Kuntze & Ad & 2.33 & - & 2.103 & 2.21 \\
\hline Sagittaria guayanensis Kunth & $\mathrm{Am}$ & 1.25 & - & 5.69 & 3.47 \\
\hline Trapa bispinosa Roxb. & $\mathrm{Ad}$ & 1.05 & - & 1.58 & 1.31 \\
\hline Total & & 52.74 & 59.57 & 69.91 & 64.44 \\
\hline \multicolumn{6}{|l|}{ Emergent species } \\
\hline Achyranthes aspera $\mathrm{L}$. & Ad & 3.03 & 3.15 & 2.03 & 2.73 \\
\hline Alternanthera sessilis (L.) D.C & Ad & 2.25 & 4.30 & 1.62 & 2.72 \\
\hline Argemone mexicana $\mathrm{L}$. & Ad & 3.36 & 6.61 & 2.90 & 4.29 \\
\hline Atylosia scarabaeoides (L.) Benth. & Ad & - & 2.25 & 3.72 & 1.99 \\
\hline Blyxa aubertii Rich. & Am & 2.78 & 4.47 & 6.52 & 4.59 \\
\hline Calotropis procera (Aiton) W.T.Aiton & Ad & 1.86 & 3.10 & 3.43 & 2.79 \\
\hline Cannabis sativa $\mathrm{L}$. & Ad & 3.08 & 7.19 & 3.45 & 4.57 \\
\hline Senna tora (L.) Roxb. & Ad & 6.37 & 8.18 & 3.38 & 5.97 \\
\hline Chrozophora rottleri (Geiseler) Spreng & Ad & 4.95 & 6.84 & 1.46 & 4.41 \\
\hline Croton bonplandianus Baill & Ad & 1.70 & 3.03 & 1.67 & 2.8 \\
\hline Cynodon dactylon (L.) Pers. & Am & 15.34 & 20.07 & 11.07 & 15.82 \\
\hline Cyperus rotundus $\mathrm{L}$. & Am & 4.26 & - & 4.76 & 3.00 \\
\hline Cyperus sp. L. & Am & 0.98 & 4.01 & 1.03 & 2.0 \\
\hline Echinochlora crus-galli (L.) P.Beauv. & Am & 4.25 & 6.31 & 3.49 & 4.68 \\
\hline Eclipta prostrata $(\mathrm{L}.) \mathrm{L}$. & Ad & 1.03 & 4.01 & 3.32 & 2.78 \\
\hline Equisetum debile Roxb.ex. Vaucher & $\mathrm{P}$ & - & 5.41 & 1.43 & 2.94 \\
\hline Euphorbia hirta L. & Ad & 3.05 & - & 2.27 & 1.77 \\
\hline Evolvulus nummularius (L.) L. & Ad & 3.71 & 4.97 & 3.16 & 3.94 \\
\hline Imperata cylindrica (L.) P. Beauv. & Am & 3.19 & 5.21 & 3.54 & 3.98 \\
\hline Ipomoea carnea Jacq. & $\mathrm{Ad}$ & 24.67 & 21.17 & 17.11 & 20.98 \\
\hline
\end{tabular}


Lantana camara $L$.

Lippia nodiflora (L.) Michx.

Leucas indica (L.) R.Br.

Leucas aspera (Willd.) Link

Ludwigia adscendens (L.) H. Hara

Mimosa pudica L.

Panicum paludosum Roxb.

Paspalum distichum L.

Paspalidium flavidum (Retz.) A. Camus.

Persicaria barbata (L.) H. Hara

Persicaria lapathifolia (L.) Delarbre

Saccharum spontaneum L.

Schonoplectus mucronatus (L.) Palla

Scripus sp. L.

Solanum nigrum L.

Stellaria media (L.) Vill.

Typha angustifolia L.

Vetiveria zizanioides (L.) Nash

Xanthium strumarium L.
Ad

Ad

Ad

Ad

Ad

Ad

Am

Am

Am

Ad

Ad

Am

Am

Am

Ad

Ad

Am

Am

$\mathrm{Ad}$
3.37

2.31

2.51

3.75

3.50

$-$

1.41

5.51

3.77

3.93

4.09

2.55

5.50

28.01

2.12

4.50

29.01

1.80

1.52

195.49

195.49

Grand Total

4.82

6.13

4.22

3.60

3.84

9.80

4.69

2.73

1.61

3.17

3.28

$-$

1.37

10.14

6.82

13.94

3.43

2.52

\begin{tabular}{ll}
$-\quad 1.72$ \\
\hline
\end{tabular}

2.23

7.95

25.56

$2.17 \quad 1.23$

3.01

$21.15 \quad 4.15$

$2.35 \quad 1.4$

1.4
1.69

1.76

208.98

178.47

178.47

$\mathrm{Al}=$ Algae, $\mathrm{Am}=$ Angiosperm (monocot), $\mathrm{Ad}=$ Angiosperm $($ dicot $), \mathrm{P}=$ Pteridophyta

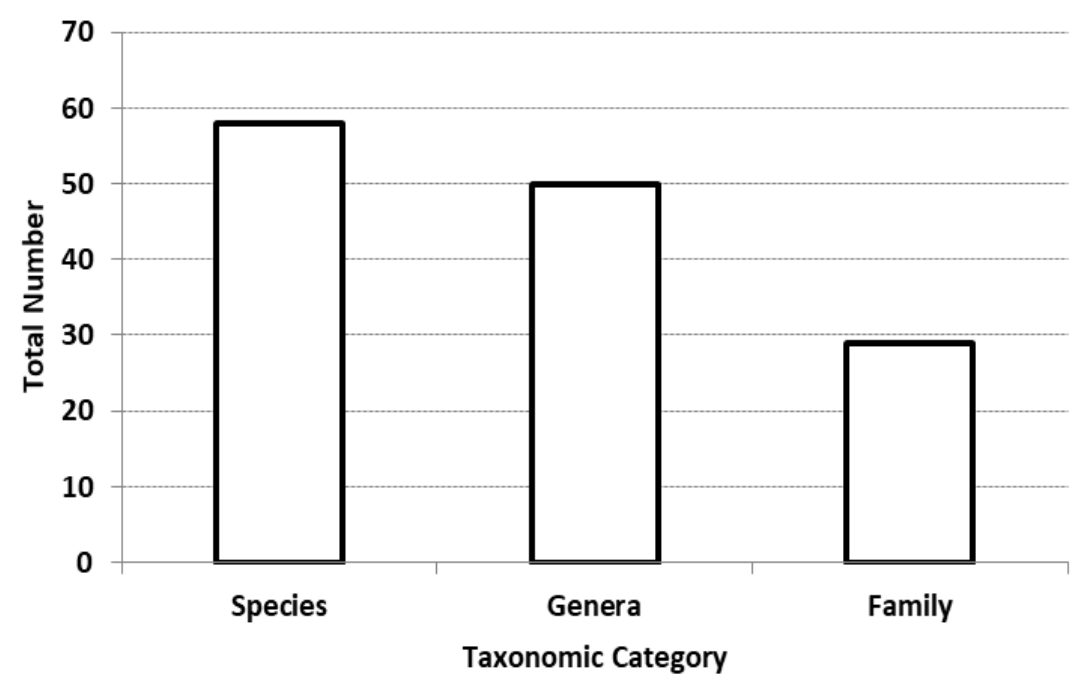

Figure 2. Total number of species by taxonomic category.

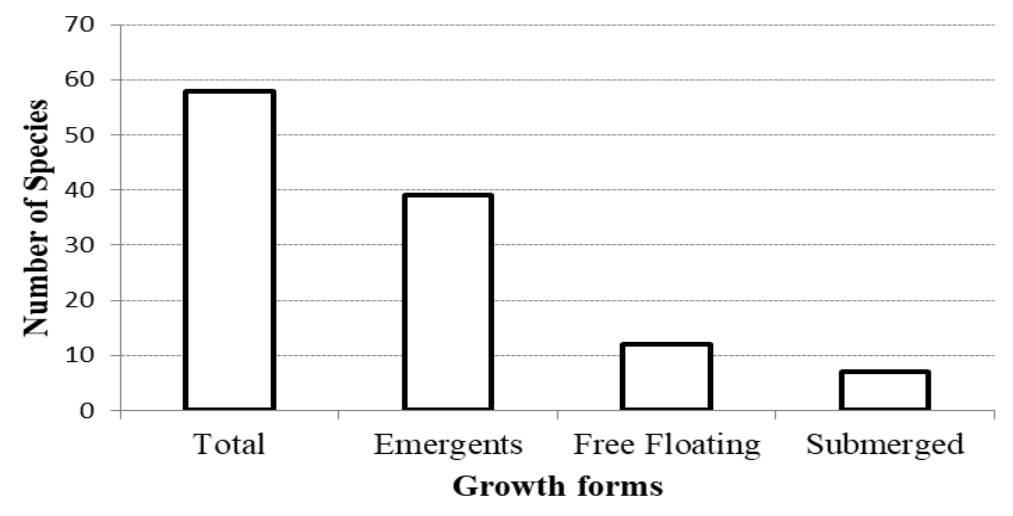

Figure. 3. Number of species by Growth form. 


\section{Chaudhary and Devkota / Our Nature | December 2021 | 19(1): 62-69}

\section{Shannon-Weiner's Diversity Index}

The computation of Shannon-Weiner Diversity Index (H') of macrophytes revealed that the species diversity was highest for emergents (2.31) in summer followed by the submerged and rooted floating leaf type species, respectively (Table 2). The highest species diversity for the entire community was found in the summer (3.451) as compared to 3.135 in the rainy season and 3.008 in the winter. The average value for the community as a whole was found to be $3.198 \pm 0.042$. Also, in a particular season, the diversity of different growth forms varied (Table 2). For example, in summer season, the highest diversity was found for emergents (2.31) followed by submerged (0.821) and rooted floating-leaf type (0.32). The same seasonal trend was reported by Valk and Davis (1976) and Handoo and Kaul (1982) in their studies. Species diversity is a useful parameter for the comparison of communities under the influence of biotic disturbance or to know the state of succession and stability in the community (Sharma and Deka, 2014). The seasonal variations in miscellaneous growth forms may cause the variations in the species diversity. The diversity index $\left(\mathrm{H}^{\prime}\right)$ for macrophyte ranged from 3.008-3.451 in Jagadishpur reservoir. These are comparable with those reported form several Asian countries, viz., Burlakoti and Karmacharya (2004) in Beeshazar, Chitwan, Nepal (3.17-4.17); Sharma (2008) in Jammu and Kashmir, India (0.511.50); Sarmah and Baruah (2015) in Morikhaboloo beel (wetland) of river Subansiri, Assam (2.51-3.21).

Table 2. Seasonal variations in Shannon-Weiner Diversity Index (H') value in different growth forms of macrophytes of Jagadishpur Reservoir.

\begin{tabular}{lcccc}
\hline \multirow{2}{*}{ Growth forms of species } & \multicolumn{3}{c}{ Shannon-Weiner Index (H) } & \multirow{2}{*}{ Mean \pm} \\
\cline { 2 - 4 } & Summer & Rainy & Winter & \\
\hline Submerged & 0.821 & 0.932 & 0.917 & $0.89 \pm 0.045$ \\
Rooted floating & 0.320 & 0.301 & 0.271 & $0.297 \pm 0.04$ \\
Emergent & 2.310 & 1.952 & 1.820 & $2.027 \pm 0.35$ \\
\hline Total community value & 3.451 & 3.135 & 3.008 & $3.198 \pm 0.042$ \\
\hline
\end{tabular}

The present quantitative analysis and diversity study of macrophytes shows a definite indication of significant changes in the macrophytic community of Jagadishpur reservoir. The most significant change in macrophytic community may be due to heavy siltation in the catchment area of the lake is due to various anthropogenic activities depending on their influx in different seasons.

\section{Conclusion}

The abundant growth of the macrophytes in the littoral zone of the Jagadishpur reservoir reveals the dynamic nature of the wetland. The dominance of emergents among other growth forms (as shown by IVI dimensions) indicates the disturbance caused by the various anthropogenic activities. Based on the above results, it can be concluded that the Jagadishpur reservoir showed high diversity of macrophytes during summer season. The obtained ShannonWiener diversity index value indicates rich species diversity in the reservoir. The fact that emergents have the highest species diversity and lowest free-floating species signifies the increasing richness in species with decreasing water level.

\section{References}

Acharya, P. 1997. Wetland vegetation and its utilization in Ghodaghodi and Nakhrodi Tal, Kailali, Nepal. Central Department of Botany, Tribhuvan University, Kathmandu. (M.Sc. Thesis)

Baral, H. S. and C. Inskipp 2005. Important bird areas in Nepal: Key sites for conservation. Bird Conservation Nepal and BirdLife International. Kathmandu and Cambridge.

Bhandari, B (ed.) 1998. An inventory of Nepal's Terai Wetlands. IUCN, Kathmandu, Nepal. xv +329 p.

Bhusal, A. and A. Devkota 2020. Environmental variables and macrophytes of lakes of the Chitwan National Park, Central Nepal. Limnol. Rev. 20(3): 135-144. 10.2478/limre-2020-001.

BPP 1995. Biodiversity assessment of Terai wetlands. Kathmandu: Biodiversity Profile Project. Department of National 


\section{Chaudhary and Devkota / Our Nature | December 2021 | 19(1): 62-69}

Park and Wildlife Conservation, HMGN. Biodiversity Profiles Project Technical Publication no.1. ix +80 p.

Burlakoti, C. and S.B. Karmacharya 2004. Quantitative analysis of macrophytes of Beeshazar Tal, Chitwan, Nepal. Him. J. Sci. 2(3): 37-41.

Chung, I.H. and S.S. Jeng 1974. Heavy metal pollution of Ta-Tu River. Bulletin of the Institute of Zoology, Academy of Science 13: 69-73.

Cook, C.D.K. 1996. Aquatic and wetland plants of India. Oxford University Press, New York. 385p

Curtis, J.T. and R.P. McIntosh 1951. An upland forest continuum in the prairie forest border region of Wisconsin. Ecology 32: 476-98.

Dembitsky, V.M., T. Rezanka and I.A. Bychek 1992. Fatty acid and phospholipids from lichens of the order Leconorales. Phytochemistry 31: 851-853.

Dhonju, M. 2010. Status and human impact assessment of Jagdishpur Reservoir - A Ramsar Site, Nepal. Central Department of Environmental Science, Tribhuvan University, Nepal. (M.Sc. Thesis)

Dinerstein, E. 1974. Vegetation analysis of Rapti river bank and its adjoining flood plain. Forestry 4: 16-23.

Gurung, V.L. 1991. Ferns: The beauty of Nepalese flora. Sahayogi Press Pvt. Ltd., Kathmandu. 234p.

Handoo, J.K. and V. Kaul 1982. Phytosociological and crop studies in wetlands of Kashmir. In Wetland Ecology and Management (Gopal, B. and R.E. Turner eds.), International Scientific Publications, Jaipur, India.

Kaul, V., C.L. Trisal, and J.K. Handoo 1978. Distribution and production of macrophytes of some aquatic bodies of Kashmir. In Glimpses of Ecology (Singh, J.S. and B. Gopal eds.). International Scientific Publications, Jaipur, India. pp. 313-334.

Khan, M.S. and M. Halim 1987. Aquatic angiosperms of Bangladesh. Bangladesh National Herbarium, Bangladesh. 120p.

Kunwar, D. and A. Devkota 2012, Seasonal variation on physico-chemical parameters and macrophytes production of Rupa Lake, Kaski, Nepal, J. Nat. Hist. Mus. 26: 80-87.
Nichols, S.A. 1992. Depth, substrate and turbidity relationships of some Wisconsin lake plants. Transactions, Wisconsin Academy of Science, Arts and Letters 80: 97-118.

Niraula, R. 2012. Evaluation of the limnological status of Beeshazar Lake, a Ramsar site in Central Nepal. Journal of Water Resource and Protection 4(5): 256-263. DOI: $10.4236 /$ jwarp. 2012.45028

Odum, E.P. 1996. Fundamentals of ecology $\left(3^{\text {rd }}\right.$ ed.). Nataraj Publishers, Dehra Dun, India. 574p.

Piecznyska, E. 1990. Littoral habitats and communities. In Guidelines of lake management, Vol. 3 (Jorgensen, S.E. and H. Loeffler eds.). International Lake Environment Committee and UNEP, Japan. pp. 39-71.

Press, J.R., K.K. Shrestha, and D.A. Sutton 2000. An annotated checklist of flowering plants of Nepal. British Museum of Nature History, London and Central Department of Botany, Tribhuvan University, Kathmandu. 430 + xii p.

Sah, J.P. 1997. Koshi Tappu wetlands: Nepal's Ramsar sites. IUCN, Bangkok, Thailand.

Sarmah, B.P. and D. Baruah 2015. Quantitative analysis of macrophytes of Morikhaboloo beel (Wetland) of River Subansiri, Assam. Der Pharmacia Lettre 7(9): 209-214.

Scheffer, M. 1989. Alternative stable states in eutrophic freshwater systems: A minimal model. Hydrobiol. Bull. 23: 7383.

Sharma, C.K. 1973. Geology of Nepal. S. Sharma, Kathmandu. 189p.

Sharma, R.C. and S. Singh 2017. Macrophytes of sacred Himalayan lake Dodi Tal, India: Quantitative and diversity analysis. Biodiversity Int. J. 1(4): 137144. DOI: $10.15406 /$ bij.2017.01.00020.

Sharma, S. 2008. Macrophytic diversity and state of environment of three lakes of Jammu Province. Proceeding of Taal 2007: the 12th World Lake Conference. pp. 2081-2087.

Sharma, S.K. and U. Deka 2014. Quantitative analysis of macrophytes and physicochemical properties of water of two wetlands of Nalbari district of Assam, 
India. Scholars Research Library, Ann. Biol. Res. 5(5): 77-84.

Shinghal, P.K. and J.S. Singh 1978. Ecology of Nainital lakes: Morphometry and macrophytic vegetation. Trop. Ecol. 19(2): 178-186.

Shrestha, P. 1998. Aquatic weeds of the Pokhara valley lakes: Status review and management perspectives. In Present status of fisheries research, development and education in Nepal. (Pradhan, B.R., S.K. Wagle, Y. Osamu, and T. Masakazu eds.). Natural Water Fisheries Development Project, Nepal Agricultural Research Council and Japan International Cooperation Agency. pp. 141-149.

Shrestha, P. 2000. Vegetation analysis of aquatic macrophytes by using line intercept in Lake Phewa, Nepal. Ecoprint 7(1): 7-14.

Singh, N. and R.C. Sharma 2014. Some important attributes which regulates the life of macro-invertebrates: A review. Int. J. Recent Sci. Res. 5(2): 357-361.

Valk, A.G. van der and C.B. Davis 1976. Changes in the composition, structure and production of plant communities along a perturbed wetland coenocline. Vegetation 32(2): 87-96.

Wetzel, R.G. 1983. Limnology ( ( $^{\text {nd }}$ ed.). Saunders College Publishing, Philadelphia. xii $+767+\mathrm{R} 81+\mathrm{I} 20 \mathrm{p}$

Zobel, D.B., P.K. Jha., U.K. Yadav, and M.J Behan 1987. A practical manual for ecology. Ratna Book Distributors, Kathmandu. 149p. 